\title{
Standardization of optimum sieve size for maximizing seed quality in Amaranthus (Amaranthus tricolor L.)
}

\author{
Pavithra M* \\ Department of Seed Science and Technology, Tamil Nadu Agricultural University, Coimbatore \\ -641003 (Tamil Nadu), India \\ J. Renugadevi \\ Department of Seed Science and Technology, Tamil Nadu Agricultural University, Coimbatore \\ -641003 (Tamil Nadu), India

\section{R. Swarna Priya} \\ Department of Vegetable Science, Tamil Nadu Agricultural University, Coimbatore - 641003 \\ (Tamil Nadu), India

\section{R. Vigneshwari} \\ Department of Seed Science and Technology, Tamil Nadu Agricultural University, Coimbatore \\ -641003 (Tamil Nadu), India \\ *Corresponding author. Email: paviuvassri@gmail.com
}

\section{How to Cite}

Pavithra, M. et al. (2021). Standardization of optimum sieve size for maximizing seed quality in Amaranthus (Amaranthus tricolor L.). Journal of Applied and Natural Science, 13(4), 1326 - 1331. https://doi.org/10.31018/jans.v13i4.3052

\begin{abstract}
Vegetables have a critical function in human health and nutritional security. Vegetables are considered an essential building block of any diet. Out of the leafy vegetables, Amaranthus is the most popular and salable vegetable consumed by people all over India. Seed processing experiment was undertaken in Amaranthus tricolor (CO 2) by using the sieves placed inside the mechanical seed shaker (Gyratory sieve shaker) to improve the quality of Amaranthus seeds. The seeds of Amaranthus were size graded with seed shaker attached with various sieve size of BSS $18 \times 18(R)$, BSS $20 \times 20(R)$, BSS $22 \times 22(R)$ and BSP $22 \times 22(P)$. During processing, the machine could be adjusted for 2, 3, 4 and 5 minutes with an oscillating speed of $1440 \mathrm{rpm}$. The separated seeds were evaluated for seed quality characteristics such as seed germination percentage, shoot length, root length, dry matter production, 1000 seed weight and seed recovery percentage. The results revealed that the sieve size of BSS $22 \times 22$ (R=retained) mesh sieve had the better quality seeds with a maximum recovery of $67.41 \mathrm{~g}$ and when it is operated for a period of 5 minutes. The germination percentage was improved from $77 \%$ to $95 \%$ with 1000 seed weight of $73.21 \mathrm{mg}$, and the observed recovery was 56 per cent with the vigour index of 1145 . Hence, BSS $22 \times 22$ retained mesh sieve with a duration of 5 minutes could be recommended as an optimum sieve size for grading Amaranthus seeds for improving the seed quality.
\end{abstract}

Keywords: Amaranthus tricolor, Gyratory sieve shaker, Seed size grading, Seed germination, Seed quality

\section{INTRODUCTION}

Amaranthus belongs to the family Amaranthaceae and is a native to North America, comes under the group of C4 plant and is distinguished by its high photosynthesis productivity. It is also known as pseudo cereals and pigweeds, It possesses three times the calcium and vitamin $B$ of spinach leaves, as well as twenty times the iron of lettuce (Bradtke, 2013). Hence, it is known as "Poor Man's Spinach". In Mexico, Amaranthus seeds are used to make "Alegria", known as popcorn cookies. Chandraprakash et al., (2019) indicated that when the weight of the seed in castor drops, the oil and protein

\section{content reduces.}

According to Shevtsova and Krol (1976), the seeds produced at different positionwould influence the yield and the quality of the produced seeds. Seeds harvested from central umbels produced productive plant in carrot. Due to indeterminate flowering behaviour of Amaranthus tricolor var. $\mathrm{CO} 2$, posing a problem for seed processing were many ill-filled and immature seeds are produced by late-formed spikes. Hence, an attempt was undertaken to access the influence of grading seeds through seed shaker with various sieve size to upgrade the quality of Amaranthus var seeds $\mathrm{CO}_{2}$. 


\section{MATERIALS AND METHODS}

Seed processing experiment was conducted at Agricultural Engineering College and Research Institute, Tamil Nadu Agricultural University, Coimbatore, by operating seed shaker model (Gyratory sieve shaker) (Plate 1). The separated seeds are tested for it's quality parameters in the Department of Seed Science and Technology, Agricultural College and Research Institute, Coimbatore. The seed shaker was filled with $100 \mathrm{~g}$ of freshly collected Amaranthus tricolor (CO 2) seeds. It works on the principle of size separation. The seeds were sorted by size using the sieves viz., BSS $18 \times 18(\mathrm{R})$, BSS 20 $X 20(\mathrm{R})$, BSS $22 \times 22(\mathrm{R})$ and BSS $22 \times 22$ (Passed out seeds of BSS $22 \times 22$ ) in a nest. The seeds are subjected to agitation for a period of 2, 3, 4 and 5 minutes, with an rpm of 1440 .

A sample of $100 \mathrm{~g}$ seeds was deposited on top of the sieve. Sieves of different sizes were arranged in a nest. The coarsest sieves are at the top of a nest then the whole sieve set is fixed to the mechanical shaker apparatus and then shaken for a period of 2-5 minutes. Each sieve's retained seeds and these seeds were weighed. Vibratory motion, side tap motion, and rotational motion had an impact on how the sieves move on and the following determinations were made on the above size grades as well as the control (ungraded) seeds viz., 1000 seed weight (International Seed Testing Association, 1999) was determined by recording the mean of eight replications and expressed in milligram. For germination percentage, 100 seeds were germinated at the temperature of $25 \pm 1^{\circ} \mathrm{C}$ and $\mathrm{RH} 95 \pm 2 \%$ with diffused light in 4 replications. After eight days, the seedlings were evaluated and the normal seedlings produced were counted and expressed in per cent as per the ISTA (1999). From the germinated seedlings, root length $(\mathrm{cm})$, shoot length $(\mathrm{cm})$, dry matter production (mg/10 seedlings) were observed. The vigour index was calculated using the following formula as per Abdul -baki and Anderson (1973) and expressed in the whole number:

Vigour index $=$ Germination (\%) $\mathrm{x}$ Total seedling length (cm) .......... Eq. 1 The resultant data were analysed statistically as per Completely Randomized Design to note the variance and evaluated (t-tested) for a significant difference of $(P=0.05)$ as proposed by Panse and Sukhatme (1999), Percentage values were transformed to sine values prior to statistical analysis.

\section{RESULTS AND DISCUSSION}

The highest seed recovery percentage was recorded in the sieve size of BSS $22 \times 22$ retained seeds irrespective of the time duration. The seed recovery percentage ranged from $67.41 \%-56 \%$ for a period of 2 minutes to 5 minutes. The seed recovery percentage decreased with an increase in the time period of seed grading. The seed recovery of 2 minutes and 3 minutes graded seeds and 4 minutes and 5 minutes graded seeds were on par with each other. The seed graded for 2 minutes recorded a 1000 seed weight of $61.21 \mathrm{mg}$ and with increased time duration, the 1000 seed weight showed higher values of $63.74 \mathrm{mg}, 67.32 \mathrm{mg}$ and $73.21 \mathrm{mg}$. Similarly, the other seed quality parameter recorded a similar trend by recording $77 \%$ germination for 2 minutes, $89 \%$ for 3 minutes, $91 \%$ for 4 minutes and $95 \%$ for 5 minutes (Table 1 to 4 ).

The highest recovery was observed in the treatment of $\mathrm{T}_{4}$ (BSS $22 \times 22 \mathrm{R}=67.41 \%$ ) under an agitation period of 2 minutes followed by $\mathrm{T}_{5}$ (BSS $22 \times 22$ (P) $(29.14 \%)$ but the other quality parameters such as
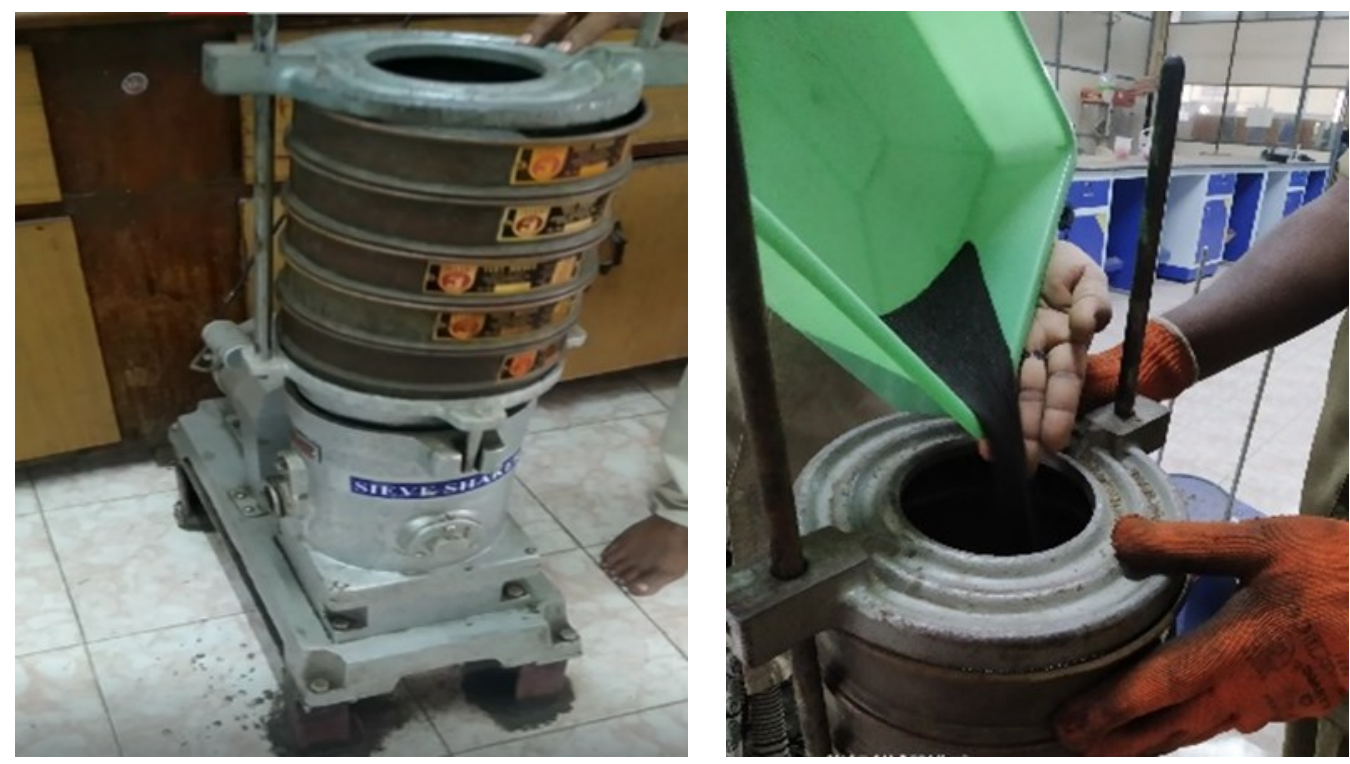

Plate 1. Gyratory Seed shaker for size grading 
Pavithra, M. et al. / J. Appl. \& Nat. Sci. 13(4), 1326 - 1331 (2021)

\begin{tabular}{llllllll}
\multicolumn{2}{l}{ Table 1. Standardization of optimum sieve size for a period of 2 minutes } & & \\
\hline $\begin{array}{l}\text { Treatment/Size } \\
\text { grades (BSS) }\end{array}$ & $\begin{array}{l}\text { Seed } \\
\text { Recovery } \\
(\%)\end{array}$ & $\begin{array}{l}\text { 1000 seed } \\
\text { weight } \\
\text { (mg) }\end{array}$ & $\begin{array}{l}\text { Germina- } \\
\text { tion } \\
(\%)\end{array}$ & $\begin{array}{l}\text { Root } \\
\text { length } \\
\text { (cm) }\end{array}$ & $\begin{array}{l}\text { Shoot } \\
\text { length } \\
\text { (cm) }\end{array}$ & $\begin{array}{l}\text { Dry matter } \\
\text { production (mg) }\end{array}$ & $\begin{array}{l}\text { Vigour } \\
\text { Index }\end{array}$ \\
\hline $\mathrm{T}_{1}-$ Ungraded & - & 55.32 & $72(58.053)$ & 5.7 & 3.1 & 10.01 & 721 \\
$\mathrm{~T}_{2}-18 \times 18(\mathrm{R})$ & 0.16 & 72.91 & $91(72.544)$ & 6.7 & 3.5 & 13.17 & 1198 \\
$\mathrm{~T}_{3}-20 \times 20(\mathrm{R})$ & 2.86 & 67.25 & $88(69.734)$ & 6.5 & 3.1 & 12.18 & 1072 \\
$\mathrm{~T}_{4}-22 \times 22(\mathrm{R})$ & 67.41 & 61.21 & $77(61.343)$ & 6.3 & 3.4 & 11.63 & 896 \\
$\mathrm{~T}_{5}-22 \times 22(\mathrm{P})$ & 29.14 & 53.72 & $60(50.769)$ & 5.1 & 3.0 & 7.63 & 458 \\
$\mathrm{SEd}$ & 0.0765 & 3.1488 & 0.4806 & 0.0880 & 0.0434 & 0.1451 & 18.9402 \\
$\mathrm{CD}(\mathrm{P}=0.05)$ & 0.1666 & 6.6754 & 1.0472 & 0.1917 & 0.0946 & 0.3161 & 41.2676 \\
\hline
\end{tabular}

Table 2. Standardization of optimum sieve size for a period of 3 minutes

\begin{tabular}{llllllll}
\hline $\begin{array}{l}\text { Treatment/Size } \\
\text { grades (BSS) }\end{array}$ & $\begin{array}{l}\text { Seed } \\
\text { Recovery } \\
(\%)\end{array}$ & $\begin{array}{l}\mathbf{1 0 0 0} \text { seed } \\
\text { weight } \\
(\mathbf{m g})\end{array}$ & $\begin{array}{l}\text { Germina- } \\
\text { tion } \\
(\%)\end{array}$ & $\begin{array}{l}\text { Root } \\
\text { length } \\
(\mathbf{c m})\end{array}$ & $\begin{array}{l}\text { Shoot } \\
\text { length } \\
(\mathbf{c m})\end{array}$ & $\begin{array}{l}\text { Dry matter } \\
\text { production } \\
(\mathbf{m g})\end{array}$ & Vigour Index \\
\hline $\mathrm{T}_{1}-$ Ungraded & - & 55.32 & $72(58.053)$ & 5.7 & 3.1 & 10.01 & 721 \\
$\mathrm{~T}_{2}-18 \times 18(\mathrm{R})$ & - & - & - & - & - & - & - \\
$\mathrm{T}_{3}-20 \times 20(\mathrm{R})$ & 2.95 & 69.71 & $93(74.660)$ & 7.1 & 3.8 & 14.17 & 1318 \\
$\mathrm{~T}_{4}-22 \times 22(\mathrm{R})$ & 66.56 & 63.74 & $89(70.632)$ & 6.9 & 3.7 & 11.72 & 1043 \\
$\mathrm{~T}_{5}-22 \times 22(\mathrm{P})$ & 29.87 & 55.36 & $63(52.536)$ & 5.1 & 2.9 & 8.47 & 534 \\
$\mathrm{SEd}$ & 0.5253 & 0.8218 & 1.0295 & 0.0299 & 0.0393 & 0.2333 & 18.7009 \\
$\mathrm{CD}(\mathrm{P}=0.05)$ & 1.1446 & 1.7906 & 2.2431 & 0.0652 & 0.0857 & 0.5084 & 40.7462 \\
\hline
\end{tabular}

Table 3. Standardization of optimum sieve size for a period of 4 minutes

\begin{tabular}{llllllll}
\hline Treatment & $\begin{array}{l}\text { Seed } \\
\text { Recovery } \\
(\%)\end{array}$ & $\begin{array}{l}\text { 1000 seed } \\
\text { weight } \\
(\mathbf{m g})\end{array}$ & $\begin{array}{l}\text { Germina- } \\
\text { tion } \\
(\%)\end{array}$ & $\begin{array}{l}\text { Root } \\
\text { length } \\
(\mathbf{c m})\end{array}$ & $\begin{array}{l}\text { Shoot } \\
\text { length } \\
(\mathbf{c m})\end{array}$ & $\begin{array}{l}\text { Dry matter } \\
\text { production } \\
\text { (mg) }\end{array}$ & Vigour Index \\
\hline $\mathrm{T}_{1}$ - Ungraded & - & 55.32 & $72(58.053)$ & 5.7 & 3.1 & 10.01 & 721 \\
$\mathrm{~T}_{2}-18 \times 18(\mathrm{R})$ & - & - & - & - & - & - & - \\
$\mathrm{T}_{3}-20 \times 20(\mathrm{R})$ & 3.29 & 74.32 & $95(77.081)$ & 6.8 & 3.2 & 16.34 & 1552 \\
$\mathrm{~T}_{4}-22 \times 22(\mathrm{R})$ & 56.53 & 67.32 & $91(72.544)$ & 6.7 & 3.4 & 13.17 & 1198 \\
$\mathrm{~T}_{5}-22 \times 22(\mathrm{P})$ & 40.18 & 57.62 & $65(53.730)$ & 5.8 & 2.9 & 7.26 & 472 \\
$\mathrm{SEd}$ & 0.2573 & 0.5463 & 0.7778 & 0.0563 & 0.0625 & 0.1678 & 13.1205 \\
$\mathrm{CD}(\mathrm{P}=0.05)$ & 0.5607 & 1.1902 & 1.6947 & 0.1227 & 0.1361 & 0.3655 & 28.5874 \\
\hline
\end{tabular}

1000 seed weight $(72.91 \mathrm{mg})$, germination percentage $(91 \%)$, root length $(6.7 \mathrm{~cm})$, shoot length $(3.5 \mathrm{~cm})$, dry matter production $(13.17 \mathrm{mg} / 10$ seedlings) and vigour index $\mathrm{II}=1198$ were observed to be higher in $\mathrm{T}_{2}$ (BSS $18 \times 18 \mathrm{R})$ but with lowest recovery of $0.16 \%$. According to Paramasivam (1990), higher germination, vigour index and other quality attributes in large seeds of peas than the smaller ones. Sieve size of BSS $20 \times 20 \mathrm{R}$ and BSS $22 \times 22 \mathrm{R}$ were on par. The seeds passed out through BSS $22 \times 22$ had the lowest germination (60\%) than the ungraded seeds (72\%) (Table 1). Germination was higher in heavier seeds due to a well-developed embryo and sound seed filling resulting in a huge amount of energy that is expressed in seedling length and seedling vigour (McDaniel, 1969).

Under the agitation period of 3 minutes, the seeds with the highest recovery $(66.56 \%)$ were observed to be high in $\mathrm{T}_{4}$ (BSS $22 \times 22 \mathrm{R}$ ) with $89 \%$ germination, root length $(6.9 \mathrm{~cm})$, shoot length $(3.7 \mathrm{~cm})$, DMP (11.72 $\mathrm{mg} / 10$ seedlings) and vigour index II (1043), whereas the lowest recovery $\left(2.95 \%\right.$ ) was observed in $\mathrm{T}_{3}$ (BSS $20 \times 20$ ) with the highest seed quality parameters 
Table 4. Standardization of optimum sieve size for a period of 5 minutes

\begin{tabular}{llllllll}
\hline Treatment & $\begin{array}{l}\text { Seed } \\
\text { Recovery } \\
(\%)\end{array}$ & $\begin{array}{l}\text { 1000 seed } \\
\text { weight } \\
(\mathbf{m g})\end{array}$ & $\begin{array}{l}\text { Germina- } \\
\text { tion } \\
(\%)\end{array}$ & $\begin{array}{l}\text { Root } \\
\text { length } \\
(\mathbf{c m})\end{array}$ & $\begin{array}{l}\text { Shoot } \\
\text { length } \\
(\mathbf{c m})\end{array}$ & $\begin{array}{l}\text { Dry matter pro- } \\
\text { duction } \\
(\mathbf{m g})\end{array}$ & $\begin{array}{l}\text { Vigour } \\
\text { Index }\end{array}$ \\
\hline $\mathrm{T}_{1}-$ Ungraded & - & 55.32 & $72(58.053)$ & 5.7 & 3.1 & 10.01 & 721 \\
$\mathrm{~T}_{2}-18 \times 18(\mathrm{R})$ & - & - & - & - & - & - & - \\
$\mathrm{T}_{3}-20 \times 20(\mathrm{R})$ & 3.93 & 77.14 & $97(80.028)$ & 7.9 & 3.9 & 15.33 & 1487 \\
$\mathrm{~T}_{4}-22 \times 22(\mathrm{R})$ & 56.00 & 73.21 & $95(77.081)$ & 7.2 & 3.6 & 14.31 & 1145 \\
$\mathrm{~T}_{5}-22 \times 22(\mathrm{P})$ & 40.07 & 60.24 & $68(55.551)$ & 6.1 & 3.2 & 9.84 & 669 \\
$\mathrm{SEd}$ & 0.1394 & 1.1937 & 0.4842 & 0.0787 & 0.0584 & 0.1546 & 7.7262 \\
$\mathrm{CD}(\mathrm{P}=0.05)$ & 0.3036 & 2.6009 & 1.0550 & 0.1715 & 0.1273 & 0.3369 & 16.8341 \\
\hline
\end{tabular}

(Table 2), because of the increased seed size and nutritional reserves. Patil and Sarode (1988) found that the seed weight of the heaviest graded seeds in agricultural crops was greater and heavier than the light and lighter seeds. According to Manikandan and Srimathi (2014), 1000 seed weight was higher in the heaviest fraction of seed gathered.

When seed shaker was operated under 4 minutes, the maximum level of seed recovery (55.63\%) was noted in $\mathrm{T}_{4}$ (BSS $22 \times 22 \mathrm{R}$ ) with germination percentage (91 $\%)$, root length $(6.7 \mathrm{~cm})$, shoot length $(3.4 \mathrm{~cm})$, DMP (13.17 mg/10 seedlings) and Vigour Index (1198), whereas $\mathrm{T}_{3}$ (BSS $20 \times 20 \mathrm{R}$ ) had top most level of 1000 seed weight $(74.32 \mathrm{mg})$ with minimum recovery percentage of $3.29 \%$ which will be uneconomical for commercial purpose. Seed quality parameters lesser than ungraded seeds were observed in $T_{5}$ (BSS $22 \mathrm{X}$ $22 \mathrm{P}$ ). Hence, $\mathrm{T}_{4}$ (BSS $22 \times 22 \mathrm{R}$ ) was considered suitable treatment under 4 minutes duration with fine seed quality characteristics and maximum recovery (Table 3). Palanisamy (1990) reported that the superiority of large and medium-size seeds would influence the via- bility of tomatoes

When seed shaker was ruined for a period of 5 minutes, the highest recovery (56\%) was observed under $\mathrm{T}_{4}$ (BSS $22 \times 22$ ) with 1000 seed weight of 73.21 $\mathrm{mg}$, germination $(95 \%)$, root and shoot length $(7.2 \mathrm{~cm}$ and $3.6 \mathrm{~cm})$, DMP (14.31 mg/10 seedlings) and vigour index (1145). Hence, $\mathrm{T}_{4}$ (BSS $22 \times 22 \mathrm{R}$ ) was considered to be a suitable treatment (Table 4). Pandita and Randhawa (1996) suggested that sowing of medium to large size seeds will significantly increase seed yield and quality in beet leaves. Several studies like that of Sivasubramaniam (2008) in kolinji (Nigella sativa), Jerlin et al. (2010) in jute (Corchorus capsularis); Sadeghi et al. (2011) in safflower (Carthamus tinctorius); Udhaya et al. (2016) in sunn hemp (Crotalaria juncea); Ragupathi (2017) in proso millet(Panicum miliaceum); Sivasubramaniam et al. (2017) in tephrosia (Terphrosia purpurea) and Pozhilarasi et al. (2018) in amaranthus ( $A$. viridis) reported a positive association between size and weight of seeds.

Various parameters observed on BSS $22 \times 22 \mathrm{R}$ sieve under the duration of $2,3,4$ and 5 minutes were tabu-

Table 5. Fixation of suitable sieve size with optimum duration for effective grading

\begin{tabular}{|c|c|c|c|c|c|c|c|c|c|}
\hline S.NO & $\begin{array}{l}\text { Duration } \\
\text { (minutes) }\end{array}$ & $\begin{array}{l}\text { Sieve } \\
\text { size }\end{array}$ & $\begin{array}{l}\text { Seed } \\
\text { Recov- } \\
\text { ery (\%) }\end{array}$ & $\begin{array}{l}1000 \text { seed } \\
\text { weight } \\
\text { (mg) }\end{array}$ & $\begin{array}{l}\text { Germi- } \\
\text { nation } \\
(\%)\end{array}$ & $\begin{array}{l}\text { Root } \\
\text { length } \\
\text { (cm) }\end{array}$ & $\begin{array}{l}\text { Shoot } \\
\text { length } \\
(\mathrm{cm})\end{array}$ & $\begin{array}{l}\text { Dry matter } \\
\text { Produc- } \\
\text { tion (mg) }\end{array}$ & $\begin{array}{l}\text { Vig- } \\
\text { our } \\
\text { index }\end{array}$ \\
\hline 1 & 2 & & 67.41 & 61.21 & $\begin{array}{l}77 \\
(61.343)\end{array}$ & 6.3 & 3.4 & 11.63 & 896 \\
\hline 2 & 3 & & 66.56 & 63.74 & $\begin{array}{l}89 \\
(70.632)\end{array}$ & 6.9 & 3.7 & 11.72 & 1043 \\
\hline 3 & 4 & & 56.53 & 67.32 & $\begin{array}{l}91 \\
(72.544)\end{array}$ & 6.7 & 3.4 & 13.17 & 1198 \\
\hline 4 & 5 & $\begin{array}{l}\text { BSS- } \\
22 \times 22\end{array}$ & 56.00 & 73.21 & $\begin{array}{l}95 \\
(77.081)\end{array}$ & 7.2 & 3.6 & 14.31 & 1359 \\
\hline Sed & & & 0.7844 & 0.5011 & 0.6504 & 0.0616 & 0.0615 & 0.1809 & $\begin{array}{l}16.423 \\
0\end{array}$ \\
\hline$C D(P=0.05)$ & & & 1.7091 & 1.0919 & 1.4172 & 0.1342 & 0.1340 & 0.3943 & $\begin{array}{l}35.782 \\
9\end{array}$ \\
\hline
\end{tabular}



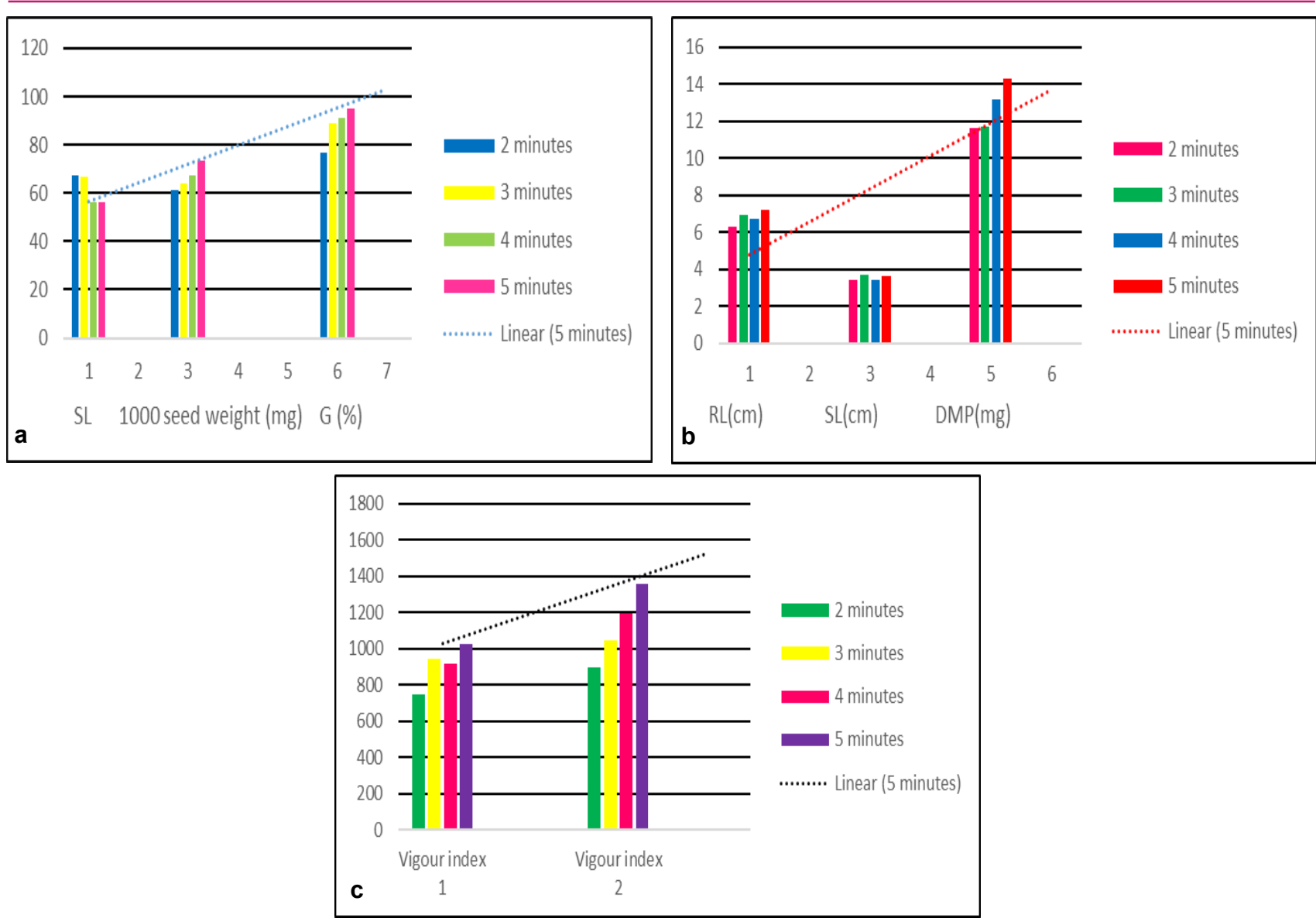

Fig. 1 a-c. Graphical representation of suitable sieve size with optimum duration for effective grading, a) Seed recovery percentage b) Root length, shoot length and Dry matter production c) Vigour Index (SL-Shoot length, G (\%)-Germination per cent, RL-Root length, SL-Shoot length, DMP-Dry matter production

lated in Table 5. Since large seeds have faster breaks in the embryonic axis with increased activity of redox enzyme that breaks the larger complex reserve food materials into simpler soluble sugars and also in other seed parts than small seeds, which have the lowest germination, large seeds have the highest germination (Negi et al., 1998.) and the size of the seeds may have a direct impact on the seedling vitality. Recovery percentage was higher under a duration of 2 minutes $(67.41 \%)$ followed by 3 minutes $(66.56 \%), 4$ minutes $(56.53 \%)$ and 5 minutes (56\%). The study indicated that the larger seeds retained by BSS $22 \times 22 \mathrm{R}$ showed greater seed germination and vigour than smaller ones (Fig. 1 a and b). This will define that huge seeds have a mature embryo with larger food reserves and nutrients, providing physiological stamina to the seeds (Pollock and Roos, 1972). The most important parameter, i.e., vigour index was observed to be higher under a period of 5 minutes [vigour index I (1026) and vigour index II (1359) (Fig.1 c). Yogeesha et al. (2013) found that heavier seed weight was associated with the highest vigour index in okra. Menaka and Balamurugan (2008) reported that heavier seed weight was associated with the highest vigour index in Amaranthus.

\section{Conclusion}

Seed recovery and maximum quality parameters were considered the most important criteria for quality seed production and greens cultivation under a commercial scale. Considering this criterion BSS 22 X $22 \mathrm{R}$ mesh sieve was standardized as a suitable sieve for grading Amaranthus. It is recommended that for obtaining the maximum quantity of quality seeds through size grading in Amaranthus CO 2, the seeds should be graded by a mechanical seed shaker for a duration of 5 minutes with the sieve size of BSS $22 \times 22$.

\section{Conflict of interest}

The authors declare that they have no conflict of interest.

\section{REFERENCES}

1. Abdul-Baki, A. A. \& Baker, J. E. (1973). Changes in cellular organelles for membranes related to vigour loss in seed. Seed Sci. \& Technology., 1, 89-125.

2. Bradtke, B.(2013).Growing Amaranth as a food plant. Retrieved from http://www.Tropical permaculture.com/ amaranth-plant.html. 
3. Chandraprakash, R., Masilamani, P., Rajkumar, P., Geetha, R., Albert, V. A. \& Eevera,T. (2019). Effect of specific gravity separation on seed germination and biochemical potential of castor hybrid YRCH1. Journal of Pharmacognosy and Phytochemistry, 8(4), 2369-2373.

4. ISTA, (1999). International Rules for Seed Testing. Seed Sci. \& Technol., Supplement Rules, 27, 25-30.

5. Jerlin, R., Menaka, C., Raja, K. Moorthy, K.R. and Tamilkumar, P. (2010). Standardization of sieve size for grading of olitorius jute seeds. Asian J. Agric. Res., 4, 1519.

6. Manikandan, S. \& Srimathi, P. (2014). Studies on postharvest seed handling techniques on grain amaranth (Amaranthus hypochondriacus L.) cv. Suvarna. Current Biotica, 8(2), 13241.

7. McDaniel, R. G. (1969). Relationships of seed weight, seedling vigor and mitochondrial metabolism in barley 1. Crop Science, 9(6), 823-827.

8. Menaka, C. \& Balamurugan, P. (2008). Seed grading techniques in Amaranthus Cv. CO5. Plant Archives, 8(2), 729-731.

9. Negi, H. C. S., Kant, K., \& Verma, M. M. (1988). Improving germination by grading in soybean. Seeds and Farms, 14 (1), 17-19.

10. Pandita, V. K. \& Randhawa, K. S. (1996). Effect of seed size and leaf cutting on seed productivity and quality in beet leaf. Seed Research, 24, 156-157

11. Panse, V. G., \& Sukhatme, P. V. (1954). Statistical methods for agricultural workers. Statistical methods for agricultural workers.

12. Palanisamy, V. (1990). Viability vigour and storage potential of seeds In different genotypes of tomato (Lycopersicon esculentum Mill.) (Doctoral dissertation,Tamil Nadu Agricultural University; Coimbatore).

13. Paramasivam, V. (1990). Studies on development, maturation, quality \& storability of pea (Pisum sativum L.)
Seeds (Doctoral dissertation, Tamil Nadu Agricultural University, Coimbatore)

14. Patil, V. N. \& Sarode, S. D. (1998). Seed quality in wheat as influenced by specific gravity separation. Seed Res., 16(1), 114-116.

15. Pollock, B. M. \& Roos, E. E. (1972). Seed and seedling vigour. In: Seed Biology, I. Importance, Development and Germination, 314-387.

16. Pozhilarasi, S., Geetha, R. \& Sujatha, K. (2018). Effect of sieve size grading for getting better quality seed in Amaranthus polygonoides var. PLR1. Research Journal of Agricultural Science, 9(5), 1166- 1167. https:// doi.org/10.20546/ijcmas.2020.907.098

17. Ragupathi, K.P. (2017). Effect of foliar nutrient on crop growth, seed development, maturation, seed yield, quality and post-harvest handling in Proso millet (Panicum miliaceum L.) cv. CO (PV) 5". M.Sc., (Ag.) Thesis, TNAU, AC \& RI, Madurai.

18. Sadeghi, H., Khazaei, F., Sheidaei, S. \& Yari, L. (2011). Effect of seed size on seed germination behaviour of safflower (Cartham ustinctorius L.). J. Agric. Biol. Sci., 6, 5-8.

19. Sivasubramaniam, S., Ambika, S. \& Vetrivel, V. (2017). Influence of size grading on physiological parameters in Tephrosia (Tephrosia purpurea) MDU (KO)-1. Journal of Applied and Natural Science, 9(1), 639 -641.

20. Shevtsova, A. M. and O.N. Krol, O. N. (1976). Variability in seed quality and carrot yield.Seed Abstr., 1 (4), 834.

21. Udhaya, D. (2016). Study of certain seed technological aspects in green manures [sunnhemp (Crotalaria juncea.L), daincha (Sesbania aculeata) and manila agathi (Sesbania rostrata)]. M.Sc., (Ag.) Thesis, TNAU, AC \& RI, Madurai.

22. Yogeesha, H. S., Kashinath, B. L., Bhanuprakash, K. \& Naik, L. B. (2013). Seed quality improvement in okra through specific gravity separation. Journal of Horticultural Sciences, 8(1), 70-73. 